\title{
Factors influencing e-Procurement adoption in the Nigerian building industry
}

\section{Eziyi Offia Ibem¹, Egidario Bridget Aduwo ${ }^{1}$, Patience Tunji-Olayeni ${ }^{1}$, Emmanuel Adekunle Ayo-Vaughan $^{2}$ and Uwakonye Obioha Uwakonye ${ }^{1}$}

${ }^{1}$ Covenant University, Ota, Nigeria

${ }^{2}$ Bells University of Technology, Ota, Nigeria

\begin{abstract}
Against the backdrop of increasing adoption of e-Procurement in supply chain management, there is a need for adequate knowledge of the factors that influence the decision by organizations in the building industry to use e-Procurement. This study aims to fill the knowledge gap through investigating the factors influencing e-Procurement adoption based on the data sourced in a questionnaire survey involving 213 organizations in the building industry. The survey was conducted between June and November 2015 in Nigeria. Descriptive statistics, factor and categorical regression analyses were used to analyze the data. The results show that the three most important factors influencing the adoption of e-Procurement amongst the participants, in order of importance, were: the benefits of e-Procurement in enhancing efficiency in project delivery; eliminating geographic barriers and effective communication among project team members. The 29 factors were investigated in seven different dimensions - the benefits of e-Procurement use; level of awareness on e-Procurement in construction; and the availability and cost of e-Procurement applications emerged as the three most significant predictors of e-Procurement adoption in the survey. The study concludes by identifying strategies that should be engaged in increasing the uptake and maximizing the benefits of e-Procurement in the Nigerian building industry.
\end{abstract}

Keywords: e-Procurement, the building industry, innovation adoption, Nigeria.

Paper type: Research article

\section{Introduction}

Since the advent of the Internet in the 1990s, the use of Internet-supported information and communication technologies (ICTs) by construction firms to manage intra and inter-firm activities has been on the increase. However, one aspect of this development that has shown great potential for improving the performance of the construction industry is the use of electronic communications and transaction processes when buying supplies and services or conducting tendering for works, which is referred to as electronic (e-) Procurement (Bausa et al., 2013).

According to Williams and Hardy (2005), the adoption of ICTs in construction is a form of technological innovation. Consequently, authors (Zou and Seo, 2006; Laryea and Ibem, 2014) have described e-Procurement in construction as innovation adoption. The existing published works have explored the use of e-Procurement in construction in several countries, including the USA (Issa $e t$

Copyright: Construction Economics and Building 2016. C) 2016 Eziyi Offia Ibem, Egidario Bridget Aduwo, Patience Tunji-Olayeni, Emmanuel Adekunle Ayo-Vaughan and Uwakonye Obioha Uwakonye. This is an Open Access article distributed under the terms of the Creative Commons Attribution 4.0 Unported (CC BY 4.0) License (https://creativecommons.org/licenses/by/4.0/), allowing third parties to copy and redistribute the material in any medium or format and to remix, transform, and build upon the material for any purpose, even commercially, provided the original work is properly cited and states its license.

Citation: Ibem, E.O., Aduwo, E.B., Tunji-Olayeni, P., Ayo-Vaughan, E.A. and Uwakonye, U.O. 2016. Factors influencing eProcurement adoption in the Nigerian building industry. Construction Economics and Building, 16(4), 54-67. DOI: http://dx.doi.org/10.5130/AJCEB.v16i4.4984

Corresponding author: Eziyi Offia Ibem; Email - ibem.eziyi@covenantuniversity.edu.ng

Publisher: University of Technology Sydney (UTS) ePress 
al., 2003), Canada (Rankin et al., 2006), Australia (Zuo and Seo, 2006), the UK (Eadie et al., 2007; 2010; 2011), Nigeria (Oyediran and Akintola, 2011) and South Africa (Ibem and Laryea, 2015). Others have examined the strategic, opportunistic and operational benefits (Eadie et al., 2007; 2010; Farzin and Nezhad, 2010), barriers (Eadie et al., 2007; 2010; Isikdag et al., 2011; Aduwo et al., 2016) of e-Procurement and the factors influencing its adoption in supply chain management (Teo et al., 2009; Daud et al., 2013). Hashim et al. (2014:231), however, noted that e-Procurement in construction was not widespread, and that there has been limited research into the factors affecting its adoption in this industry. Ibem and Laryea (2015) have observed that this is particularly evident in African countries where e-Procurement adoption in construction related areas appears to be at its nascent stage.

It was against this background that the current study investigated the factors influencing eProcurement adoption in the Nigerian building industry (NBI). The objectives were to:

- identify the key factors considered important in the decision by organizations in the NBI to adopt e-Procurement;

- investigate the dimensions of the factors that influenced the decision by organizations in the NBI to adopt e-Procurement; and

- identify the factors that contribute the most to explaining the actual use of e-Procurement by organizations in the NBI.

This study relied on empirical data derived from a questionnaire survey of architectural, building construction and quantity surveying firms, client organizations and government agencies in the NBI to achieve these objectives. The study contributes to knowledge by identifying the factors considered important in the decision to use e-Procurement by organizations in the NBI. It also extends knowledge on which of these factors contribute the most to explaining actual use of eProcurement in construction; and thus it is a valuable contribution to the current discourse on eProcurement in construction from the Nigerian perspective.

\section{Review of literature}

The review of literature covers two main areas. First, is the presentation of the underpinning theoretical framework of this study; and second, is the review of previous studies on the factors influencing e-Procurement adoption in construction.

\section{Theoretical background}

The adoption of a new idea, process, product or service (i.e. innovation) has been explained from diverse perspectives in the literature. For example, Klein et al. (2001:811) described adoption as a decision to use an innovation within the organization, while Rogers (2003) defined adoption as a decision to make full use of an innovation (p.177). Rogers also made it clear that the decision to adopt an innovation consists of five phases of awareness, interest, evaluation, trial and adoption (Rogers, 2003). Further, Woodside and Biemans (2005:384-385) described adoption as "the decision-making process of an individual unit of adoption to use a product or service. Therefore, in this study, e-Procurement adoption refers to the actual use of web-based technologies, tools or processes to support the execution of some or all aspects of construction procurement activities.

In the research literature, a number of theories have been engaged in studies on the adoption of new technologies. Some of these theories include: the diffusion of innovation (DOI) theory by Everett M. Rogers in 1962; the technology, organization and environment (TOE) framework by Tornatzky and Fleischer (1990); the technology acceptance model (TAM); theory of reasoned action (TRA) and unified theory of acceptance and use of technology (UTAUT)(Tran et al, 2011). However, Oliveira 
and Martins (2011) noted that whereas the DOI and TOE framework are relevant in the study of technology adoption at the firm's (organizational) level, the TAM, TRA and UTAUT are useful in studies that explore innovation adoption by individuals. Since the focus of the current research is on e-Procurement adoption by organizations, the DOI theory and TOE framework are considered to be relevant in this study.

Roger's DOI theory posits that among other factors, the attributes of an innovation influence its diffusion and adoption (Rogers, 2003). He identified these attributes to include: i) relative advantage (the extent to which the innovation is viewed to be better than the existing idea, practice, knowledge or tool by users; i.e. perceived cost and benefits); ii) compatibility (the degree to which an innovation is consistent with the existing practice, experience, norms, needs and value system of the potential adopters); iii) complexity (the degree to which an innovation is perceived as difficult to understand and use); iv) trialability (the degree to which an innovation may be experimented with on a limited basis); and v) observability (the degree to which the results of adoption of innovation are visible to others) (Rogers, 2003). Although Rogers (2003) was of the view that these attributes account for between $49 \%$ and $87 \%$ of variation in the adoption of innovation, Ibem and Laryea (2015) noted that the three attributes consistently found to be relevant to innovation adoption are relative advantage, compatibility and complexity. Mustonen-Ollila and Lyytinen (2003) explained that the factors identified by Rogers are perception measures that represent independent variables used in exploring the likelihood and propensity to, or actual adoption of, an innovation as the dependent variable.

Although Roger's DOI theory has been applied in ICT diffusion and adoption studies in construction (see Songip et al., 2013; Daud et al, 2013; Ibem and Laryea, 2015 for examples), it has been criticized for not considering the influence of market and industry characteristics on adoption decisions by firms. Consequently, the TOE model developed by Tornatzky and Fleischer in 1990 seeks to address the inadequacies of the Roger's DOI theory (Teo et al., 2009; Oliveira and Martins; 2011). The TOE model contends that technological, organizational and environmental factors largely influence innovation adoption (Tornatzky and Fleischer, 1990). Oliveira and Martins (2011) explained that technological factors are concerned with the existing and emerging technologies and may include current practices, equipment and technologies within and outside the organizations. The organizational factors are mainly management structure, organizational size, scope of activities resource base and others (Azadegan and Teich, 2010), while the environmental factors are the influence of industry characteristics, competitors, government and other institutions that have influence on the adopting unit (Azadegan and Teich, 2010; Oliveira and Martins, 2011).

Compared to the manufacturing, transportation, retailing and other service industries, who are early adopters of e-Procurement (Teo et al., 2009), the construction industry is generally regarded as a late adopter of e-Procurement (Eadie et al., 2007; 2010; Laryea and Ibem, 2014). However, existing theories and conceptual frameworks do not appear to have considered the influence of early adopters of e-Procurement on the late adopters. Therefore, this study sought to include the external influence of other industries on the adoption of e-Procurement technologies and tools by organizations in the NBI.

\section{Factors influencing e-Procurement adoption in construction: a review of studies}

In the construction sector, a number of studies have attempted to explore the factors influencing an organizations' decision to adopt e-Procurement. For example, Rankin et al. (2006) found that the decision to adopt e-Procurement by 226 organizations in the Atlantic Canadian AEC industry was influenced by the perceived benefits of e-Procurement in gaining access to a larger market and increased opportunities; reduction in paperwork; increased productivity; and reduction in the procurement cycle time and transaction cost. Teo et al. (2009) also found that firm size, top 
management support, perceived indirect benefits, and business partners influenced the adoption of e-Procurement in 141 Architecture/Engineering/Construction firms in Singapore. In the UK, Eadie, et al. (2011) observed that in public and private sector organizations, there was a correlation between the size, procurement spending and sector an organization belonged to and e-Procurement use. The authors found that the perceived benefits in time and cost savings, increased quality, visibility in the supply chain, efficiency, and effective communication associated with e-Procurement were the key factors that influenced e-Procurement use. Other factors identified in that study were improved inventory management, elimination of errors and convenience of archiving of completed work.

Elsewhere in Malaysia, Daud et al. (2013) revealed that the key factors that influenced e-Procurement adoption among 178 contractors were perceived usefulness of e-Procurement technologies in handling procurement work, and the complexity of e-Procurement technologies. Similarly, Tran and Huang (2014) noted that the adoption of e-Procurement in developing countries was influenced by technological, organizational, environmental, and managerial factors. Ibem and Laryea (2015) also found that the speed of transactions, lower transaction cost and ease of use of the technologies had the highest positive impact on e- Procurement use in the South African construction industry.

It is evident from this that the attributes of e-Procurement technologies, organizational characteristics and the operating environment are amongst the factors that can influence the decision to adopt e-Procurement by organizations. It was also observed that none of the existing studies explored the influence of other industries on the adoption of e-Procurement in the construction sector. Therefore, there is a need to explore this further, particularly in a developing country like Nigeria where the literature on e-Procurement in construction is very thin.

A conceptual framework of this study was developed based on the findings of the literature review. The framework (Figure 1) proposes that the factors that influence the decision by organizations in the NBI to use e-Procurement are: (i) the attributes of e-Procurement technologies; (ii) organizational factors; (iii) environmental factors; and (iv) the influence of other industries. Therefore, in this study, the key assumption is that the decision to use e-Procurement by organizations in the NBI is a product of the attributes of e-Procurement technologies, organizational, and environment factors, as well as the influence of other industries described as early adopters of e-Procurement.

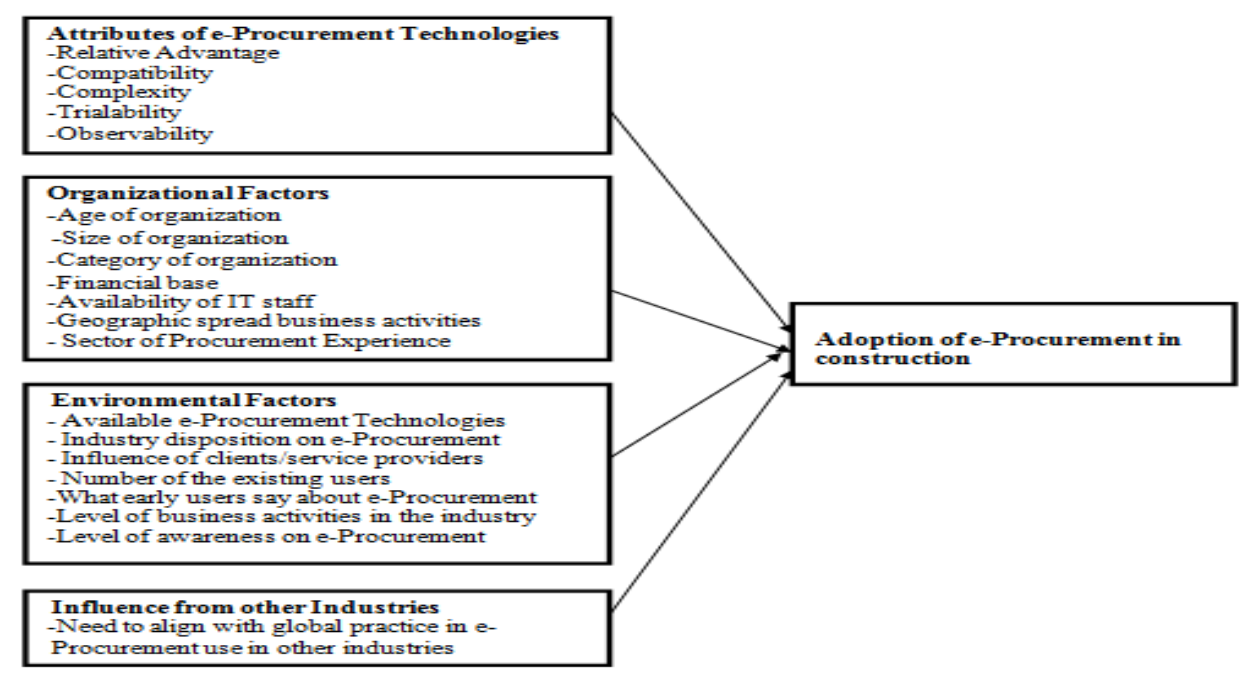

Figure 1: Conceptual framework of the study 


\section{Research method}

This study is part of a research project designed to investigate the extent of e-Procurement use in the NBI. A quantitative research approach involving a questionnaire survey was the primary data collection strategy used. Several studies (Rankin et al., 2006; Eadie et al., 2007; 2011; Ibem and Laryea, 2015; Aduwo et al., 2016) used a similar approach. The advantages of this approach include its cost effectiveness, wider coverage, and anonymity (see Bulmer, 2004 and Bird, 2009).

The researchers designed the questionnaire based on findings from the review of literature. Section 1 of the questionnaire comprised questions on the professional roles of the participants and their organizations. Section 2 included questions on their level of awareness, duration and extent of eProcurement use. In gathering data on the length of use, the participants in this research who indicated that they have used e-Procurement were asked to identify how long they have been using it based on the following options $1=$ less than one year, $2=(1$-years $) ; 3=(6-10)$ years; $4=$ Over 10 years. Section 3 contained questions on the factors influencing the decision by their organizations to adopt e-Procurement. In Section 3, the participants were asked to rate 29 factors identified from the review of literature in the order of their importance in influencing their decision to use eProcurement based on a 5-Likert type scale, where 1= "Not Important"; 2= "Least Important"; $3=$ "Undecided"; 4= "Important"; and 5= "Most Important". Table 2 presents the list of factors investigated in this research.

Prior to the main survey, the researchers carried out a pilot survey in Lagos in April 2015. In the pilot survey, the researchers sent a copy of the questionnaire to 30 purposively selected architectural, and quantity surveying firms, as well as client organizations. Of the 30 surveys sent 12 responded, a $40 \%$ response rate. Feedback from the pilot survey resulted in the adjustment of some of the questions used in the main survey. The reliability of the scale of measurement used in the questionnaire was examined using Cronbach's alpha coefficient test conducted on all 29 of the variables used. The result showed Cronbach's alpha value of 0.851 , which is more than 0.7 recommended by Pallant (2011), suggesting that the questionnaire instrument is reliable.

The main survey took place between June and November 2015. The target population was architectural, building and quantity surveying firms in the NBI. The survey of architectural firms took place in June 2015 during the 2015 Architects' Colloquium in Abuja. The survey of building construction firms took place at the Annual Builders' National Conference and Meeting at the University of Ibadan in August 2015, while data was extracted from the Quantity Surveying firms at the Annual QS Research Conference held at the Federal University of Technology, Akure in November 2015. Participants in the research were randomly selected and the questionnaire administered to them by the researchers and some trained research assistants. In addition, client organizations, including government ministries/parastatals and multinationals (e.g. oil and gas, telecommunication, manufacturing and building construction companies) in Lagos, Abuja and Port Harcourt participated in the research. To ensure that only one respondent from an organization was included in the survey, the respondents were asked to indicate the names of the organizations.

Of the 500 questionnaires distributed, 213 valid questionnaires were returned, representing around 43\% response rate. Previous studies (Rankin et al., 2006; Daud et al., 2013) had reported similar response rates. The data was analysed with the help of Statistical Package of the Social Sciences (SPSS) Version 20. Three main types of analyses were conducted. The first analysis was descriptive statistics. The mean scores for each of the 29 factors influencing the adoption e-Procurement as provided by the respondents who indicated that they have used e-Procurement were also computed. The second analysis was exploratory factor analysis using principal component analysis and Varimax rotation method. This analysis was used to address the second objective of the study. It is noteworthy that only responses from those who indicated that they have used e-Procurement were 
included in this analysis. The authors also used it to extract the factors used in the regression analysis. The third analysis conducted was the Categorical Regression Analysis with optimal scaling technique also known as CATREG in SPSS. This analysis was used to examine the variance explained by $\mathrm{R}^{2}$, identify and compare the relative strength of the factors predicting the adoption of e-Procurement among the respondents who have used e-Procurement. CATREG analysis was used in this study as the survey data included combinations of ordinal and numerical/interval variables. Hussain et al. (2006) have identified the benefits of CATREG analysis over standard regression in the analysis of dataset comprising both ordinal and numerical/interval variables. In executing the CATREG, the responses on how long the participants have used e-Procurement formed the dependent variable, while the factor scores for Factors(1-7) extracted from the exploratory factor analysis; the level of awareness on e-Procurement in construction; type and age of organizations; and sector of procurement experience by the organizations were the independent variables. This is consistent with the submission by Mustonen-Ollila and Lyytinen (2003) as previously highlighted.

\section{Study findings}

\section{Profiles of the participants and their organizations}

Table 1 shows the professional roles of the respondents in the research and profiles of their organizations. It is evident from Table 1 that around one-third of the respondents were architects and most of those sampled worked in consulting firms and government-owned organizations. The results also revealed that a high majority of the organizations were more than ten years old and consisted of more than 20 members of staff. Based on this result it is fair to assume that the key stakeholders in the NBI participated in the survey; suggesting that the findings of this research can be generalized in the context of the NBI.

\section{Level of awareness and extent of e-Procurement use}

The data collected regarding participants' levels of awareness of e-Procurement in construction shows that about $160(75.1 \%)$ of them were aware, while $47(22.1 \%)$ were not aware of eProcurement in construction, with $6(2.8 \%)$ participants not responding. The result also reveals that a majority $129(52 \%)$ of the participants had not participated in projects involving the use of eProcurement, while $84(39.4 \%)$ of the respondents stated that they have, and around $9 \%$ of the participants provided no response. Since the current research is on the factors influencing eProcurement adoption, only data provided by those (84 respondents) who indicated that their organizations have participated in projects involving the use of e-Procurement are presented in the subsequent sections of this paper. This is to ensure that the views expressed by those who have not used e-Procurement, while a useful indicator of the perception of e-Procurement, are excluded from the result presented due to their hypothetical, rather than experience based, nature.

Figure 2 shows the professional roles of the 84 respondents who have participated in building projects involving the use of e-Procurement. It is evident from this result that the highest percentage of those using e-Procurement are quantity surveyors, followed by architects, builders and others. The data indicates that the majority (61\%) have been using it for between 1 and 5 years, 23\% below 1 year, $14.3 \%$ have been using e-Procurement for between 6 to 10 years, while $2.4 \%$ have used it for over 10 years. 
Table 1: Professional Roles of the Respondents and Profiles of their Organizations

\begin{tabular}{|c|c|c|}
\hline Role/ Duty/ Profession & Frequency & Percentage \\
\hline \multicolumn{3}{|l|}{ Role in the Building Industry } \\
\hline Architect & 75 & 35.2 \\
\hline Builder & 47 & 22.1 \\
\hline Engineer & 9 & 4.2 \\
\hline Construction/ Project manager & 20 & 9.4 \\
\hline Quantity Surveyor (QS) & 56 & 26.3 \\
\hline Procurement/Supply chain manager & 6 & 1.9 \\
\hline \multicolumn{3}{|l|}{ Type of Organization } \\
\hline Consulting firms & 72 & 33.8 \\
\hline Contractors & 45 & 21.1 \\
\hline Client organizations & 21 & 9.9 \\
\hline Government Ministry/ Parastatals & 75 & 35.2 \\
\hline \multicolumn{3}{|l|}{ Sector of Procurement experience } \\
\hline Public sector only & 36 & 16.9 \\
\hline Private sector only & 52 & 24.4 \\
\hline Both public and private & 125 & 58.7 \\
\hline \multicolumn{3}{|l|}{ Staff Strength (Persons) } \\
\hline Below 20 & 94 & 44.1 \\
\hline $20-50$ & 45 & 21.1 \\
\hline $51-100$ & 14 & 6.6 \\
\hline More than 100 & 56 & 26.3 \\
\hline No response & 4 & 1.9 \\
\hline \multicolumn{3}{|l|}{ Age of Organization } \\
\hline Below 5 years & 31 & 14.6 \\
\hline $6-10$ years & 52 & 24.4 \\
\hline More than 10 years & 126 & 59.2 \\
\hline No response & 4 & 1.9 \\
\hline \multicolumn{3}{|l|}{ Number of Offices in Nigeria } \\
\hline One & 84 & 39.4 \\
\hline Two & 52 & 24.4 \\
\hline Three & 17 & 8.0 \\
\hline More than three & 42 & 19.7 \\
\hline No response & 18 & 8.5 \\
\hline \multicolumn{3}{|c|}{ Range of annual turnover in Naira (1\$US= $\$ 314.62)$} \\
\hline Less than 100 million & 91 & 42.7 \\
\hline 100-500 million & 40 & 18.8 \\
\hline 600 million-1 billion & 17 & 8.0 \\
\hline Over 1 billion & 42 & 19.7 \\
\hline No response & 23 & 10.8 \\
\hline
\end{tabular}

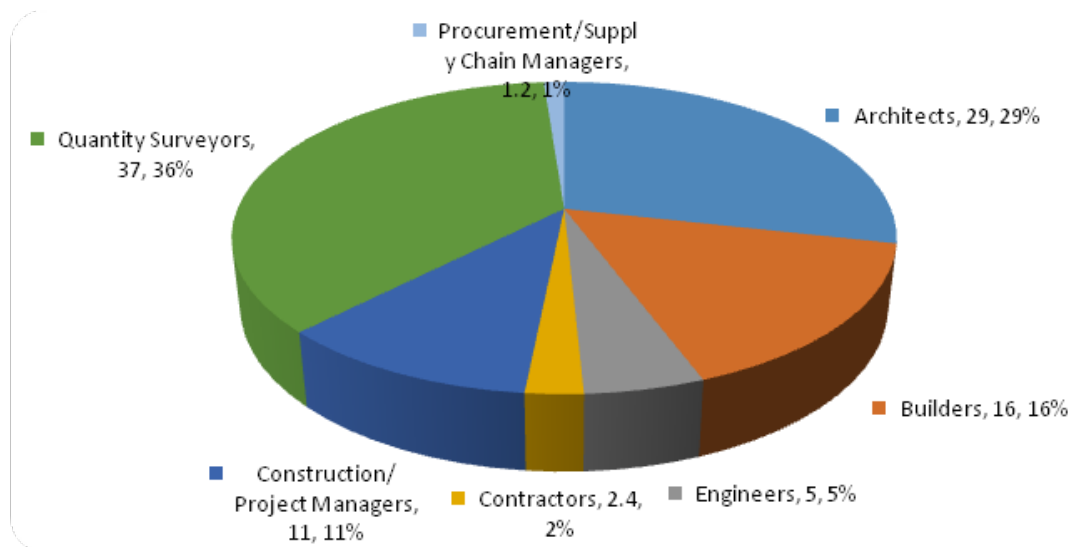

Figure 2: Professional background of the users of e-Procurement 


\section{Factors influencing e-Procurement use}

The 84 respondents who are users of e-Procurement were also asked to rate the factors that influenced their decision to adopt e-Procurement. The results displayed in Table 2 show that the factors with mean values of 4.00 and above are considered to be of the highest influence, those with mean values of between 3.50 and 3.99 are of moderate influence, while the factors with mean values of less than 3.50 are considered to be least influential.

The results in Table 2 show that the three factors with the highest influence on the decision to adopt e-Procurement by the organizations of the 84 respondents were the benefits of e-Procurement in enhancing efficiency in job delivery, eliminating geographic barriers to participation in construction procurement activities and effective communication among project team members. On the other hand, factors with the least influence on the decision to adopt e-Procurement were what early users said about e-Procurement and the result of the initial attempt at e-Procurement use in their organizations.

Table 2: Descriptive statistics of factors influencing e-Procurement use

\begin{tabular}{|l|c|c|}
\hline Factors & Mean & Std. Dev. \\
\hline Benefits of enhanced level of efficiency in job delivery & 4.73 & 5.94 \\
\hline Benefits of elimination of geographic barriers in procurement & 4.59 & 4.87 \\
\hline Benefits of effective communication between project team members & 4.20 & 0.81 \\
\hline Availability of IT manpower in my organization & 4.14 & 0.89 \\
\hline Benefits of good inventory management and record keeping & 4.13 & 0.80 \\
\hline The need to align with global trends in e-Procurement use in other industries & 4.13 & 1.10 \\
\hline Reduction in errors associated with paper-based methods & 4.08 & 0.82 \\
\hline Easier coordination of procurement activities & 4.04 & 0.92 \\
\hline Reduction in time spent on procurement process & 3.99 & 1.06 \\
\hline Less paper work & 3.99 & 0.99 \\
\hline Cost of acquiring and operating the package & 3.97 & 1.15 \\
\hline Efficiency of collaboration amongst project team & 3.97 & 0.92 \\
\hline Availability of e-Procurement packages & 3.93 & 1.07 \\
\hline Less labour intensive feature of e-Procurement & 3.90 & 0.92 \\
\hline Decision by our clients/ service providers to use e-Procurement & 3.90 & 0.99 \\
\hline Perceived benefits associated with reduction in the procurement cost & 3.89 & 1.03 \\
\hline Compatibility of e-Procurement with our existing procurement process & 3.85 & 0.95 \\
\hline Benefit of competitiveness inherent in e-Procurement & 3.82 & 0.95 \\
\hline Increase in profit margin associated with e-Procurement & 3.80 & 1.00 \\
\hline Visibility of our business inherent in e-Procurement & 3.77 & 1.04 \\
\hline Financial base of my organization & 3.73 & 1.21 \\
\hline Size of my organization & 3.71 & 1.14 \\
\hline The extent to which e-procurement technology and tools are easy to use & 3.69 & 1.10 \\
\hline Level of business activities in the construction industry in the country & 3.48 & 1.06 \\
\hline Number of existing users amongst business partners & 3.45 & 1.14 \\
\hline Geographical spread of the business activities of my organization & 3.42 & 1.15 \\
\hline What early users said about e-Procurement technologies and tools & 3.42 & 1.24 \\
\hline Result of the initial attempt at e-Procurement use in my organization & 3.25 & 1.26 \\
\hline
\end{tabular}

\section{Dimensions of the factors influencing e-Procurement use}

Exploratory factor analysis was used to investigate the dimensions of factors that influenced the organizations' decision to use e-Procurement. In order to ascertain that the data set was suitable for 
factor analysis, Kaiser-Meyer-Olkin Measure of Sampling Adequacy (KMO) and the Bartlett's Test of Sphericity were conducted. The result showed the KMO value of 0.740 and Bartlett's test, $\mathrm{p}=0.000$. These values are more than 0.6 for KMO and 0.05 for Bartlett's test as recommended by Pallant (2011), suggesting that the survey data is suitable factor analysis.

Table 3 shows the result of the exploratory factor analysis of the 29 factors influencing eProcurement use as perceived by the 84 respondents. It is evident from the results that seven dimensions of the factors that influenced the decision to adopt e-Procurement explained around $78 \%$ of the total variance in the 29 factors investigated.

Table 3: Dimensions of factors influencing e-Procurement use

\begin{tabular}{|c|c|c|c|c|}
\hline Dimensions of Evaluation & $\begin{array}{l}\text { Factor } \\
\text { Loading }\end{array}$ & Eigenvalue & $\begin{array}{l}\text { Percentage of } \\
\text { Variance }\end{array}$ & $\begin{array}{l}\text { Percentage } \\
\text { Cumulative }\end{array}$ \\
\hline Factor 1: Benefits of e-Procurement use & & 6.990 & 24.103 & 24.103 \\
\hline $\begin{array}{l}\text { Result of the initial attempt to e-procurement in my } \\
\text { organization }\end{array}$ & .458 & & & \\
\hline $\begin{array}{l}\text { The increase in profit margin associated with e- } \\
\text { procurement }\end{array}$ & .510 & & & \\
\hline Reduction in errors associated with paper-based methods & .558 & & & \\
\hline Reduction in the procurement cost & .552 & & & \\
\hline Reduction in time spent on procurement process & .527 & & & \\
\hline Enhanced level of efficiency in job delivery & .601 & & & \\
\hline Involvement of less paper work in e-Procurement & .582 & & & \\
\hline Less labour intensive feature of e-Procurement & .733 & & & \\
\hline Effective communication between project team members & .637 & & & \\
\hline $\begin{array}{l}\text { The potential of e-procurement to improve efficiency of } \\
\text { collaboration amongst project team }\end{array}$ & .534 & & & \\
\hline $\begin{array}{l}\text { The benefit of good inventory management and record } \\
\text { keeping }\end{array}$ & .554 & & & \\
\hline Easier coordination of procurement activities & .725 & & & \\
\hline Visibility of our business inherent in e-procurement & .567 & & & \\
\hline $\begin{array}{l}\text { Elimination of geographic barriers in the procurement } \\
\text { process }\end{array}$ & .594 & & & \\
\hline Factor 2: Construction industry-related factors & & 4.985 & 17.190 & 41.293 \\
\hline $\begin{array}{l}\text { Compatibility of e-procurement with the existing } \\
\text { construction procurement process }\end{array}$ & .748 & & & \\
\hline $\begin{array}{l}\text { Decision by our clients/service providers to use e- } \\
\text { Procurement }\end{array}$ & .632 & & & \\
\hline $\begin{array}{l}\text { What early users said about e-Procurement technologies } \\
\text { and tools }\end{array}$ & 679 & & & \\
\hline Scope of operational activities of my organization & .630 & & & \\
\hline $\begin{array}{l}\text { The number of existing users amongst my business } \\
\text { partners }\end{array}$ & .557 & & & \\
\hline $\begin{array}{l}\text { The level of business activities in the construction } \\
\text { industry in the country }\end{array}$ & .553 & & & \\
\hline Factor 3: Organizational characteristics & & 3.327 & 11.474 & 52.767 \\
\hline $\begin{array}{l}\text { The geographical spread of the business activities of my } \\
\text { organization }\end{array}$ & .744 & & & \\
\hline Financial base of my organization & .620 & & & \\
\hline Availability of IT manpower in my organization & .646 & & & \\
\hline
\end{tabular}




\begin{tabular}{|c|c|c|c|c|}
\hline Dimensions of Evaluation & $\begin{array}{l}\text { Factor } \\
\text { Loading }\end{array}$ & Eigenvalue & $\begin{array}{l}\text { Percentage of } \\
\text { Variance }\end{array}$ & $\begin{array}{l}\text { Percentage } \\
\text { Cumulative }\end{array}$ \\
\hline $\begin{array}{l}\text { Factor 4: The complexity and need to align with } \\
\text { global trend in the use of e-procurement } \\
\text { technologies }\end{array}$ & & 2.183 & 7.529 & 60.296 \\
\hline $\begin{array}{l}\text { Extent to which e-procurement technologies and tools } \\
\text { are easy to use }\end{array}$ & .509 & & & \\
\hline $\begin{array}{l}\text { The need to align with global trends in e- procurement } \\
\text { use }\end{array}$ & .595 & & & \\
\hline $\begin{array}{l}\text { Factor 5: Availability and cost of e-Procurement } \\
\text { Applications }\end{array}$ & & 1.993 & 6.872 & 67.168 \\
\hline Availability of e-Procurement packages & .502 & & & \\
\hline The cost of acquiring and operating the package & .607 & & & \\
\hline Factor 6: The Size of Organization & .616 & 1.767 & 6.092 & 73.260 \\
\hline $\begin{array}{l}\text { Factor 7: Benefits of Competitiveness inherent in e- } \\
\text { Procurement }\end{array}$ & .496 & 1.303 & 4.493 & 77.753 \\
\hline
\end{tabular}
$78 \%$ of the total variance

Examination of the result in Table 3 reveals that the first dimension explaining around $24 \%$ of the variance in the 29 factors investigated is related to the benefits of e-Procurement technologies and tools (Factor 1). Next is the construction industry related factors (Factor 2), explaining 17.2\% of the variance in the factors investigated; and organizational characteristics (Factor 3), explaining around $12 \%$ of the variance in all the factors examined. Others are the complexity and need to align with the global trend in the use of e-Procurement technologies (Factor 4); the availability and cost of eProcurement technologies (Factor 5); the size of organizations (Factor 6) and the benefits of competitiveness inherent in e-Procurement (Factor 7).

\section{Predictors of e-Procurement adoption}

In order to investigate the factors that contribute the most to explaining e-Procurement use in the survey, a CATREG analysis was also conducted. The result shows that the model having $\mathrm{R}^{2}=0.595$ explained around $60 \%$ of variance in the decision to use e-Procurement by the participants with $\mathrm{F}$ $(34.0,37)=15.93 \mathrm{P}<0.000$. The coefficients of the regression analysis are presented in Table 4 .

Table 4: Coefficients of the Multiple Regression Analysis

\begin{tabular}{|c|c|c|c|c|c|}
\hline \multicolumn{6}{|l|}{ Coefficients } \\
\hline & \multicolumn{2}{|c|}{$\begin{array}{l}\text { Standardized } \\
\text { Coefficients }\end{array}$} & \multirow[t]{2}{*}{ df } & \multirow[t]{2}{*}{$\mathbf{F}$} & \multirow[t]{2}{*}{ Sig. } \\
\hline & Beta & $\begin{array}{c}\text { Bootstrap } \\
(1000) \\
\text { Estimate of } \\
\text { Std. Error }\end{array}$ & & & \\
\hline Benefits of e-Procurement ( Factor 1) & 0.788 & 0.092 & 5 & 0.301 & $0.000^{*}$ \\
\hline Industry disposition on e-Procurement (Factor 2) & -0.221 & 0.103 & 5 & 1.156 & 0.070 \\
\hline Organizational characteristics (Factor 3) & 0.324 & 0.210 & 5 & 0.183 & $0.000^{*}$ \\
\hline $\begin{array}{l}\text { The complexity and need to align with global trend in the use of e- } \\
\text { procurement technologies (Factor 4) }\end{array}$ & 0.271 & 0.255 & 4 & 1.653 & 0.942 \\
\hline Availability and cost of e-Procurement Applications (Factor 5) & 0.487 & 0.021 & 4 & 0.254 & $0.001 *$ \\
\hline The Size of Organization (Factor 6) & -0.451 & 0.119 & 3 & 1.230 & $0.001^{*}$ \\
\hline Benefits of Competitiveness inherent in e-Procurement (Factor 7) & -0.127 & 0.182 & 2 & 0.825 & 0.188 \\
\hline Level of awareness on e-Procurement & 0.643 & 0.272 & 1 & 1.854 & $0.000^{*}$ \\
\hline Type of Organization & 0.100 & 0.061 & 1 & 0.835 & 0.840 \\
\hline Sector of Procurement Experience & 0.025 & 0.078 & 2 & 1.541 & 0.855 \\
\hline Age Organization & -0.012 & 0.061 & 1 & 0.123 & 0.568 \\
\hline
\end{tabular}

*significant predictors

It is evident in Table 4 that five factors emerged as the significant predictors and contributed the most to explaining e-Procurement use by the 84 respondents in the survey. The factors are: the 
benefits of e-Procurement use (Factor 1); organizational characteristics (Factor 3), the availability and cost of e-procurement technologies (Factor 5); the size of organization (Factor 6); and the level of awareness on e-Procurement in construction (Factor 7).

\section{Discussion}

The findings of this study highlighted three key issues, which are further discussed in this section of the paper. First, the study found out that the first three factors with the highest influence on the decision to use e-Procurement by the 84 respondents are related to the benefits of e-Procurement in construction. This result corresponds with previous studies (Issa et al., 2003; Rankin et al., 2006; Zuo and Seo, 2006; Eadie et al., 2007; 2010; 2011) which also showed that the perceived benefits of eProcurement was the reason why most organizations in the construction industry use it. This suggests that the decision to adopt e-Procurement by organizations in the NBI is partly influenced by the associated benefits in enhancing efficiency in project delivery, eliminating geographic barrier to participation in procurement activities and improving effective communication among project team members. This appears to be consistent with the research of Lavelle and Bardon (2009) which states that managing the entire construction procurement process electronically can promote efficiency and effectiveness in project delivery.

Second is that the study also found that although the researchers used 29 factors to investigate the decision to adopt e-Procurement as shown in Table 2, the practitioners understood these factors in seven key dimensions (Factors 1-7) as presented in Table 3. Examination of these dimensions shows that the first (Factor 1), fourth (Factor 4) and seventh dimensions (Factor 7) deal with the attributes of e-Procurement technologies (i.e. technological factors). In fact, most of the factors loaded on these three dimensions are the relative advantages of e-Procurement over the paper-based method as identified in previous studies (see Teo et al., 2009 and Eadie, et al., 2011). Therefore, apart from providing support to the TOE framework on the role of technological factors (Tornatzky and Fleischer, 1990), this finding is also consistent with Rogers' DOI theory on the role of the attributes of innovation in its diffusion and adoption as previously highlighted. Similarly, the third (Factor 3) and sixth (Factor 6) dimensions deal with organizational characteristics, while the second and fifth dimensions (Factors 2 and 5) are environmental factors. These findings are also in line with the existing literature that shows that organizational and environmental factors play prominent roles in influencing organizations' decision to adopt innovations as encapsulated in the TOE framework (Tornatzky and Fleischer 1990). Specifically, the emergence of size of the organizations as one of the dimensions in the survey may further validate the finding by Teo et al. (2009) and Eadie, et al. (2011) on the influence of the size of firms on e-Procurement adoption in Singapore and the UK, respectively.

Furthermore, in support of the assumption in the conceptual framework of this study (Figure 1), the need to align with the global practice in e-Procurement use in other industries also emerged as one of the factors in the fourth dimension. This suggests that the decision to use e-Procurement by the 84 respondents can also be linked to the desire to align with current global practice in the use of eProcurement in supply chain management in the manufacturing, transportation, retailing and other industrial sectors.

Lastly, the study also revealed that the benefits of e-Procurement use; organizational characteristics; availability and cost of e-Procurement technologies; size of organization and the level of awareness of e-Procurement in construction were the significant predictors of e-Procurement adoption in the NBI. This result is understandable since these predictors have links to the dimensions identified in the exploratory factor analysis. However, in terms of their contribution to explaining the decision to use e-Procurement by $39.4 \%$ of the respondents in the survey, it is clear that the benefits associated 
with e-Procurement use contributed most. This result was as expected given that existing studies (Ganasekaran and Ngai, 2008; Teo et al., 2009; Le et al., 2012; Bauasa et al., 2013; Bilali and Bwisa, 2015) have shown that the strategic, opportunistic and operational benefits of e-Procurement in supply chain management were the key drivers of e-Procurement use in the different industrial sectors. The second factor with the highest contribution is the level of awareness of e-Procurement in construction among the participants. The emergence of this factor was also as expected as a high level $(75 \%)$ of awareness on e-Procurement in construction was observed among the respondents. In fact, this result is in line with the research of Rogers (2003) indicating that awareness was the first in the five phases of the decision to adopt an innovation. This implies that organizations can only make the decision to use an innovation if they know of its existence.

The third most important factor influencing e-Procurement adoption was the availability and cost of e-Procurement applications. Again, this finding is consistent with previous studies (Samuelson, 2008 and Khalil and Waly, 2015) showing that stakeholders in the construction industry have generally expressed fears that the lack of access to compatible software applications and technically functional systems at an affordable cost constitute a serious impediment to e-Procurement adoption in construction. Therefore, the availability and cost of e-Procurement applications have a strong influence on the decision by organizations to use them.

\section{Limitations of the study}

The first limitation of this study is associated with the bias of the respondents, which is very common to questionnaire surveys. It is most likely that the quality of data obtained in this research is subject to the perspectives and biases of the respondents in the survey. In rating the factors influencing the decision by their organizations to adopt e-Procurement, the respondents may have given biased ratings based on their personality and other influences associated with the different roles they play and levels of employment in their organizations. The second limitation is the way this research was conducted. The research approach was limited in terms of sample size, scale of measurement used and the number of variables investigated in this study. Therefore, future studies might consider including more variables.

\section{Conclusion}

This study examined the factors influencing e-Procurement adoption in the NBI. Based on the findings the following conclusions are drawn. First is that the three most important factors in the decision by organizations to adopt e-Procurement are the perceived benefits of e-Procurement in enhancing efficiency in job delivery, eliminating geographic barriers to the participation in construction procurement activities, and effective communication between project team members. The second conclusion is that whereas the researchers viewed the factors that can influence eProcurement adoption from four main dimensions (attributes of the technology, organization and environment factors, and the influence of other industries), practitioners in the NBI understood the different factors from seven key dimensions. The last conclusion is that the factors that contribute the most to explaining e-Procurement adoption in the NBI are the benefits of e-Procurement use; level of awareness of e-Procurement use in construction; and the availability and cost of eProcurement technologies and tools.

The implications of these findings are that, as is true in other countries where e-Procurement has been adopted in construction, top of the list of the factors that influenced the decision by organizations in the NBI to adopt e-Procurement are its perceived benefits and relative advantages over the paper-based methods. The study also implies that there is a difference in the ways in which researchers and users view the factors influencing the decision to adopt e-Procurement in the 
building industry. This means that construction researchers must thrive to align their thoughts with those of practitioners in the industry for better results in their research endeavours. Another implication of this study is that for organizations that plan to adopt e-Procurement in the future, it is important that they understand the benefits, the availability and cost of e-Procurement technologies and tools. Therefore, to ensure a critical mass uptake of e-Procurement and maximize its benefits in the NBI there is a need for an increased level of awareness on e-Procurement use through workshops/conferences and professional associations; and the availability of e-Procurement technologies and tools at affordable cost.

\section{References}

Aduwo, E.B., Ibem, E.O., Tunji-Olayeni, P., Uwakonye; O.U. and Ayo-Vaughan, E.K. (2016). Barriers to the Uptake of e-Procurement in the Nigerian Building Industry. International Journal of Applied Theoretical and Applied Information Technology (IJATAIT) 89(1), p.133-147

Azadegan, A. and Teich, J. (2010) Effective Benchmarking of Innovation Adoptions- A Theoretical Framework for eProcurement Technologies. Benchmarking: An International Journal, 17(4), p.472-490. doi: https://doi.org/10.1108/14635771011060558

Bauasa, P.O., Kourtidis, S., Liljemo, K., Loozen, N., Rodrigues F.J. and Snaprud, M. (2013) E-procurement Golden Book of Good Practice. Retrieved from www.pwc.be. On 15th May 2014

Bilali, J and Bwisa, H. (2015) Factors influencing the Adoption of e-Procurement: A case of Garissa County Government. The Strategic Journal of Business \& Change Management, 35, p662-682

Bird, D.K. (2009) The use of Questionnaires for Acquiring information on Public Perception of Natural hazards and risk mitigation - a review of current knowledge and practice. Nat. Hazards Earth Syst. Sci., 9, p.1307-1325. doi: https://doi.org/10.5194/nhess-9-1307-2009

Bulmer, M. (2004) Sage Benchmarks in Social Science Research Methods, in Questionnaires, 1st edition edited by: Bulmer, M., Sage Publications, London, p.354.

Croom, S. and Brandon-Jones, A. (2004) E-Procurement: Key issues in e-Procurement implementation and operation in the public sector, 13th International Purchasing \& Supply Education \& Research Association (IPSERA) Conference, April 4-7, Catania, Italy.

Daud, N.M., Mohammad, N., Azmi, A.E. and Mohamed, I.S. (2013) Factors influencing the usage of e-Procurement among contractor companies in Malaysia. Business and Management Quarterly Review, 4(3\&4), p.62-80

Eadie, R., Perera, S., Heaney, G. and Carlisle, J. (2007) Drivers and Barriers to Public Sector e-procurement within Northen Ireland's Construction Industry. Journal of Information Technology in Construction, 12, p.103-120

Eadie, R., Perera, S. and Heaney, G. (2010) A cross-discipline comparison of rankings for e- procurement drivers and barriers within UK Construction Organizations, Journal of Information Technology in Construction, 15, p.217-23

Eadie, R., Perera, S. and Heaney, G. (2011) Analysis of the use of E-Procurement in the Public and Private Sectors of the UK construction Industry. Journal of Information Technology in Construction (ITcon), 16, p.669-686

Farzin, S. and Nezhad, H. (2010) E-Procurement, the Golden Key to Optimizing the Supply Chains System. World Academy of Science, Engineering and Technology, International Science Index42, 4(6), p.449-456

Gunasekaran, A., McGaughey, R.E., Ngai, E.W.T. and Rai, B.K. (2009) E-Procurement Adoption in the Southcoast SMEs, International Journal of Production Economics, 122(1), p.161-175. doi: https://doi.org/10.1016/i.ijpe.2009.05.013

Gunasekaran, A. and Ngai, E.W.T. (2008) Adoption of e-Procurement in Hong Kong: An empirical research, International Journal of Production Economics, 113(1), 159-175. doi: https://doi.org/10.1016/j.ijpe.2007.04.012

Hashim, N., Said I., and Idris. A.B.M. (2014) e-Procurement Implementation in Maysian Construction Industry. Aust. J. Basic \& Appl. Sci., 8(6), p.231-238

Hussain, M., Castaldi, R., and Cholette, S. (2006) Determinants of wine consumption of US Consumers: an econometric analysis. International Journal of Wine Business Research, $19 \quad$ (1), p.49-62. doi: https://doi.org/10.1108/17511060710740343 
Ibem, E.O and Laryea, S. (2015) e-Procurement use in the South African construction industry. Journal of Information Technology in Construction 20, p.364-384

Isikdag, U., Underwood, J., Ezcan, V., and Arslan, S (2011) Barriers to e-procurement in Turkish AEC industry. Proceedings of the CIB W78-W102 2011: International Conference - Sophia Antipolis, France, 26-28 October

Issa, R.R.A., Flood, I. and Caglasin, G. (2003) Survey of E-Business Implementation in the US Construction Industry. Journal of Information Technology in Construction, 8, p.15-28.

Khalil, C.A and Waly, A.F. (2015) Challenges and Obstacles facing Tenderers Adopting e- Tendering in the Public sector of the Construction Industry in Egypt. 5th International/11th Construction Specialty Conference, Vancouver, British Columbia June 8 to June 10, Retrieved https://open.library.ubc.ca/cIRcle/collections/52660/items/1.0076349 on 25th November, 2015

Klein, K. J., Conn, A. B., \& Sorra, J. S. (2001) Implementing Computerized Technology: An Organizational Analysis. Journal of Applied Psychology, 86(5), p.811-824. doi: https://doi.org/10.1037/0021-9010.86.5.811

Laryea, S. and Ibem, E.O. (2014) Patterns of Technological Innovation in the use of e- Procurement in Construction. Journal of Information Technology in Construction, 19, p.104-125,

Lavelle, D and Bardon, A. (2009) E-tendering in Construction: Time for a Change? Built Environment Research Paper, 2(2), p.104-112

Le, V. H., Rowe, F., Truex, D., and Huynh, M. Q. (2012) An Empirical Study of Determinants of E-Commerce Adoption in SMEs in Vietnam: An Economy in Transition, Journal of Global Information Management, 20(3), p.23-54. doi: https://doi.org/10.4018/igim.2012070102

Mustonen-Ollila, E. and Lyytinen, K. (2003) Why organizations adopt Information System process innovations: a longitudinal study using Diffusion of Innovation theory. Information Systems Journal, 13(3), p.275-297. doi: https://doi.org/10.1046/j.1365-2575.2003.00141.x

Oliveira, T and Martins, M.F (2011) Literature Review of Information Technology Adoption Models at Firm Level. The Electronic Journal Information Systems Evaluation, 14(1), p.110- 121

Oyediran, O.S. and Akintola, A.A (2011) A Survey of the State of the Art of E-Tendering in Nigeria. Journal of Information Technology in Construction 16, p.557-576.

Pallant, J. (2011) SPSS survival manual-a step-by-step guide to data analysis using SPSS (4th ed.). Australia: Allen and Unwin

Rankin, J., Chen, Y. and Christian, A. (2006) E-procurement in the Atlantic Canadian AEC industry, Journal of Information Technology in Construction, 11, p.75-87

Rogers, E.M. (2003) Diffusion of Innovations (5th ed.). New York: Free Press

Samuelson, O. (2008) The IT-Barometer - A Decade's Development of its Use in The Swedish Construction Sector. Journal of Information Technology in Construction, 13, p.1-19.

Songip, A.R., Lau, B. H., Jusoff, K. and Ramli, H.N. (2013) A Working Integrated Model for the Diffusion of Construction Innovation. American Journal of Applied Sciences, 10(2), p.147-158. doi: https://doi.org/10.3844/ajassp.2013.147.158

Teo, T.S.H., Lin, S. and Lai, K. (2009) Adopters and non-adopters of e-Procurement in Singapore: An empirical study, Omega, 37(5), p.972-987. doi: https://doi.org/10.1016/j.omega.2008.11.001

Tornatzky, L. and Fleischer, M. (1990) The Process of Technology Innovation, Lexington, MA, Lexington Books

Tran, Q., Huang, D., Liu, B. and Ekram, H.M. (2011) A Construction Enterprise's Readiness Level in Implementing EProcurement: A System Engineering Assessment Model, Systems Engineering Procedia, 2, p.131-141. doi: https://doi.org/10.1016/j.sepro.2011.10.016

Tran, Q. and, Huang, D. (2014) E-Procurement Institutionalization in Construction Industry in Developing Countries: A Model and Instrument. WSEAS Transactions on Computers, 13, p.152-176.

Williams, S.P and Hardy, C. (2005) Public e-Procurement as Socio-technical Change. Strategic Change. 14, p.273-281. doi: https://doi.org/10.1002/jsc.728 
Woodside, A. G., and Biemans, W.G. (2005) Modeling innovation, manufacturing, diffusion and adoption/rejection processes. Journal of Business \& Industrial Marketing, 20(7), p.380-393. doi: https://doi.org/10.1108/08858620510628614

Zuo, P.X.W and Seo, Y. (2006) Effective Applications of E-Commerce Technologies in Construction Supply Chain: Current Practice and Future Improvement. Journal of Information Technology in Construction, 11, p.127-147 